\title{
内耳奇形に眼奇形,頸椎異常を伴った症例に関する考察
}

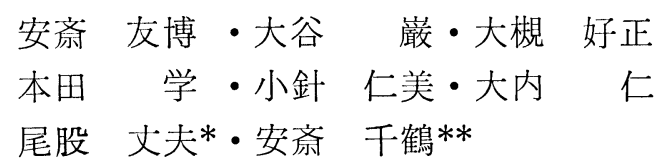

\section{A Case of Inner Ear Anomaly with Bilateral Macular Coloboma and Cervical Synostosis}

\author{
Tomohiro Anzai, Iwao Ohtani, Kohsei Ohtsuki, Manabu Honda, \\ Hitomi Kobari, Jin Ouchi and Takeo Omata \\ (Fukushima Medical College)
}

\author{
Chizuru Anzai \\ (Department of Ophthalmology, Fukushima Medical College)
}

A 22-year-old woman with an inner ear anomaly had bilateral macular coloboma and cervical synostosis. Both auricles, external auditory canals and tympanic membranes were normal, but she had total deafness of the left ear. X-ray of her left ear showed an inner ear anomaly called "a solitary sac-like deformity".

This very rare association of abnormalities did not fit any established syndrome of ear, eye and vertebral column anomalies such as Goldenhar's syndrome, Wildervanck's syndrome, etc.

は じめに

若年者に認められる一側性感音難聴は, その発症, 原因が不明なととが多い. 最近のX線学的診 断の進歩により, 蝸牛, 前庭, 前・外側半規管などの内耳迷路の診断が可能であり, 内耳の形態異 常が原因と推察される感音難聴の症例の報告が散見1),2),3)される。内耳奇形については, 従来, Ormerod ${ }^{4}$ による組織学的分類が広く知られており，中でも Michel 型は最も高度の内耳形成不全 を示し，内耳発生の初期の段階で発達が停止したものと考えられている.

小耳や内耳奇形に眼奇形々頸椎異常を有する疾患には, Goldenhar 症候群や Wildervanck 症候 群などがあるが, 最近, われわれは, これらの既知の症候群にはあてはまらない内耳奇形に両眼性 黄斑部火掂および頸椎癒合を伴った症例を経験したので文献的考察を加えて報告する.

\section{症例}

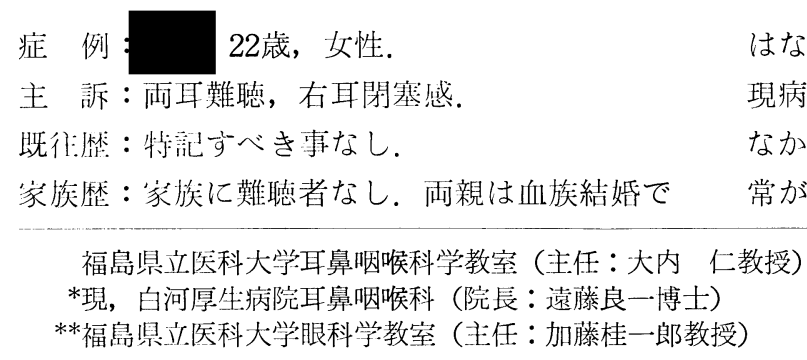

はない.

現病歴：患者の奸娠中，母胎に特に異常を認め なかった。幼児期より両眼の視力不良之眼位異 常があり，眼底の異常と外斜視を指摘され，7

*現, 白河厚生病院耳鼻咽喉科（院長：遠藤良一博士）

**福島祡站医科大学眼科学教室 (主任：加藤桂一郎教授） 
歳時に外斜視の手術を受けた。難聴の自覚はな かったが，9歳時中耳炎に罹患した際左耳の高 度難蛂を指摘された。17歳頃より右耳難聴に気 付き, 時々有耳閉塞感があった。昭和 57 年 4 月 精査のため当科を受診した。

現 症:

1.耳鼻科的所見 : 両側耳介, 外耳道, 鼓膜は 正常で, 顔面神経麻痺は認めず, 他の鼻腔, 吠 頭，喉頭に特に異常所見を認めなかった。純音 聴力検査では, 右耳は高音漸傾型の中等度感音 難聴, 左耳は全周波数で scale out を示した (図 1). 右耳の SISI test は除性, 語音聴力 検査では $65 \mathrm{~dB}$ で $90 \%$ の最高明膫度を示し, 自 記 audiometer では Jerger II 型で, TTS は 認められなかった。 Tympanogram では両側

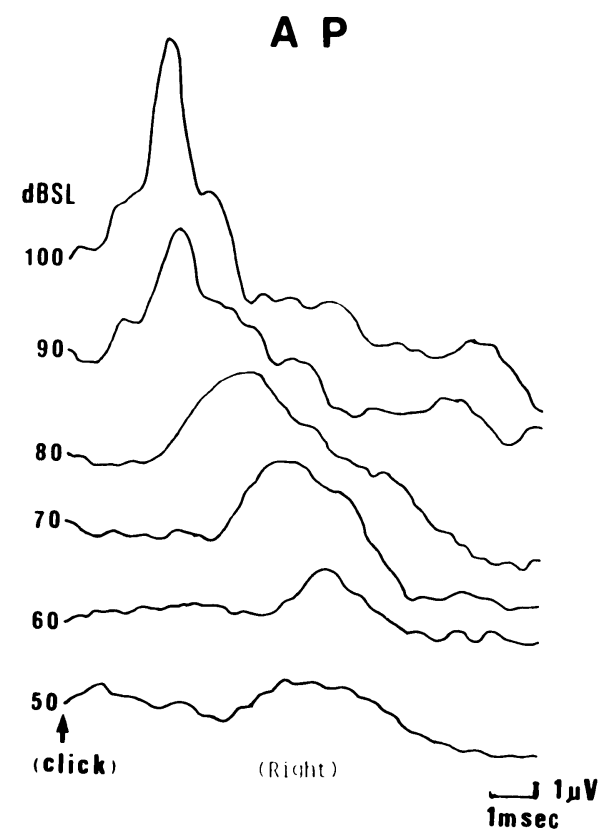

dBSL
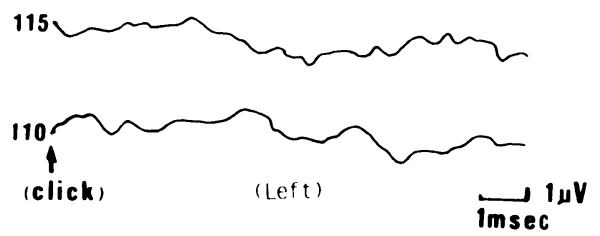

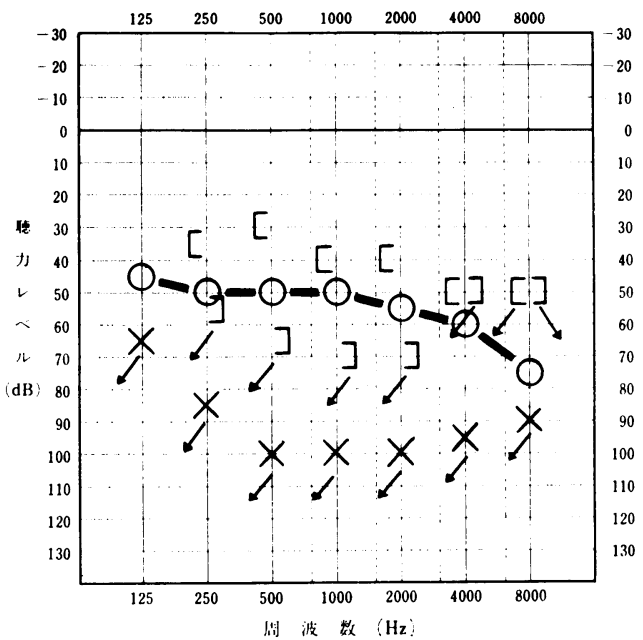

図1 聴 力 図

\section{A B R}

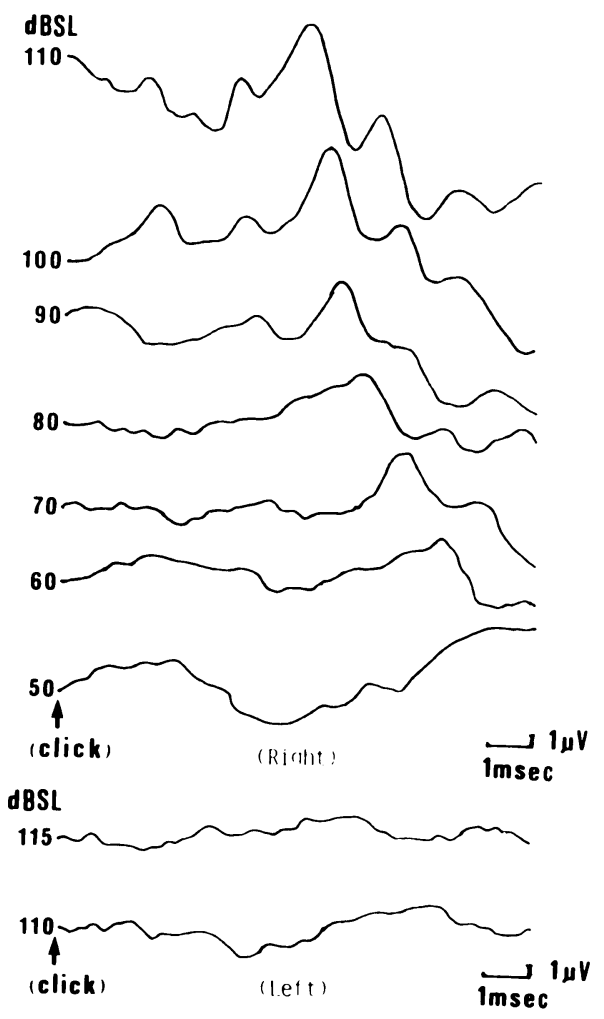

図 $2 \mathrm{AP}, \mathrm{ABR}$

右耳は, broad AP, I 波・V波の潜時の延長を認める. 左耳は，無反応. 


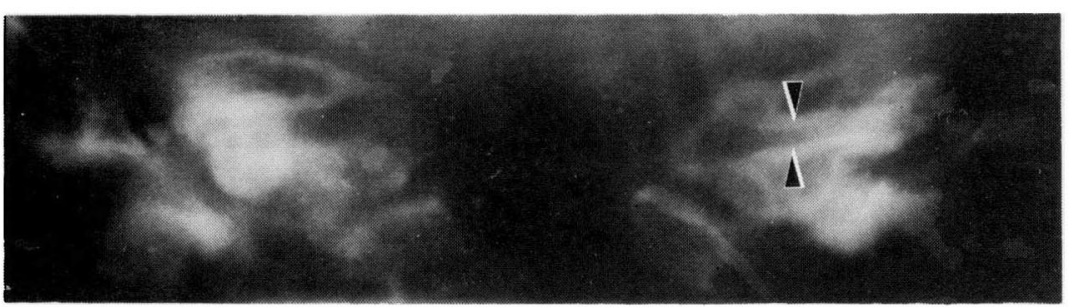

図 3 内耳道断層撮影（蝸牛面）

左蝸牛は欠如し, 内耳道は次第に狄小化している (知).

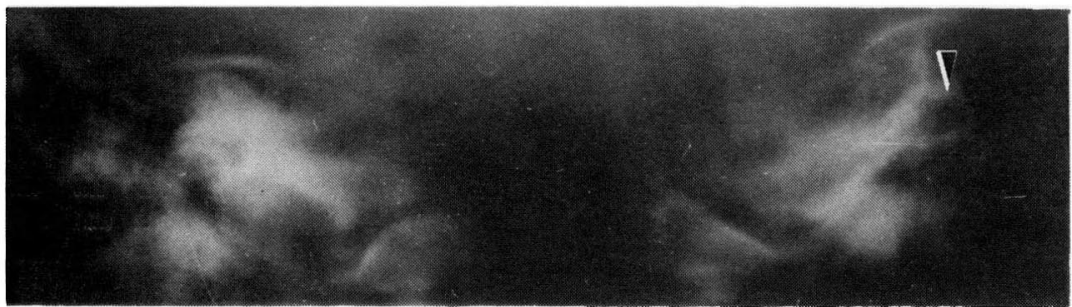

図4 内耳道断層撮影（前庭而）

左耳に空洞様構造（solitary sac-like deformity 矢印）を認める.

とも Atype を示した。前庭機能検査では自発 眼振, 注視眼振, 頭位眼振, 頭位変換眼振は認 められず，ETT, OKN は良好であったが， caloric test にて左耳の反応を認めず，CP を 呈した，脳波聴力検査では，左耳は無反応，右 耳は broad AP を示し, ABR では, 50 から $60 \mathrm{~dB}$ の閾值で，I波・V波の潜时の延長を認 めた（四 2).

X線学的に Schüller 法では, 両側とも乳资 蜂单の発育は良好で特に異常所見は認められな かった. Stenvers法では, 右耳は滘, 左耳

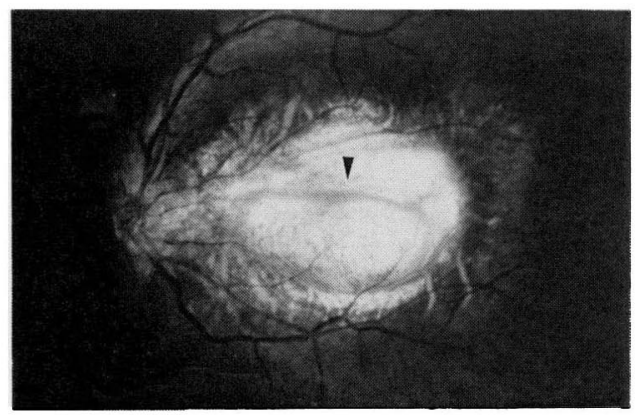

図 5 左眼底所見

黄斑部に直径 3 乳頭径の黄斑部欠損 (Macular Coloboma）を認め，脈絡膜血管（矢印）が透見 される。
側頭骨錐体部に空润様構造を認め, 内耳道は次 第に狭小化していた。内耳道断層撮影では，蝸

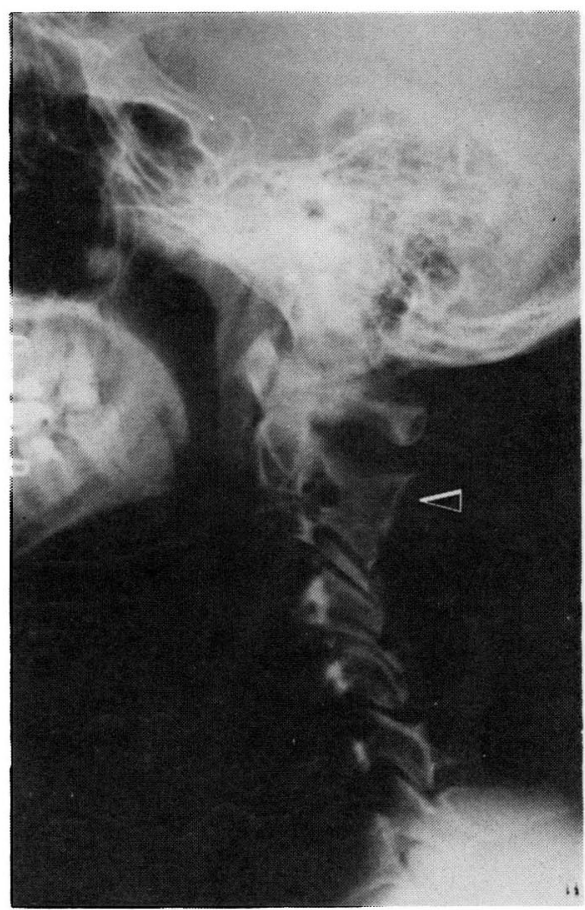

図 6 頸椎側面 $\mathrm{X}$ 線 $\mathrm{C}_{2}-\mathrm{C}_{3}$ の喻合を認める (知印). 
牛を通る面で，左耳は耳小骨は存在するが蝸牛 は欠如し，内耳道は次第に狭小化していた（図 3 ). 前庭を通る面では, 左側頭骨錐体部の上. 外側半規管，前庭に相当する部位に空洞様構造 を認めた（図 4).

2. 眼科的所見 ; 視力は $v . d=0.01(0.02 \times 2.0$ $\mathrm{D}), \mathrm{v} . \mathrm{s}=0.03(0.08 \times-4.0 \mathrm{D})$ であり, 眼球運 動や中間透光体に異常は認めなかった。しか し，両側眼底後極部に黄斑部を中心とする直径

\section{考}

聴覚, 視覚という特殊感覚器はウイルス感染 のような奇形誘発因子に非常に敏感であり，胎 生 4 週から 6 週の間に抢ける同一の因子により 重複奇形が惹起されることがある。耳と眼は， 胎生第 3 週の後期より 4 週の初期にそれぞれ表 層の神経外胚葉に由来する後脳の耳胞 (Otic vesicle あるいは Otocyst) と前脳の眼胞 (Optic vesicle) より発生を開始する。内耳の 発生 ${ }^{5,(6)}$ は, 胎生第 3 週の後期より 4 週の初期 に後脳の神経外胈葉の一部が原くなり, 耳板 (otic placode) を形成し，ての部分が内方へ 陥入する事により耳窩（otic pit）となる。さ らに宿入し, 外皮との連絡が切れて, 閒葉山に 埋没し, 囊状の構造すなわち耳胞 (otocyst) となる。耳胞は胎牛: 5 週後に上下に紐長くなり 背側部（Pars superior）は，卵非囊，半規管 内リンパ管，腹側部（Pars inferior）は，球形 囊, 蝸牛管へ之分化する。 6 週前後に球形囊, 蝸牛管が発生し， 7 週までに半規管 が分化す る. 内耳奇形は, てれらの内耳の発生, 分化す る胎生第 4 週から 8 週までの種々の段階で，何 らかの原因でその分化が停止し，それぞれの段 階に相当する種々の奇形が生じてくる.

内耳奇沜に関して, 従来より Ormerod ${ }^{4)}$ 分 類 (1. Michel 型, 2. Mondini-Alexander 型，3. Bing-Siebenmann 型，4. Scheibe型)

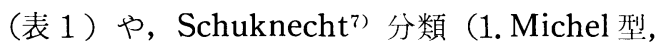
2. Mondini型, 3. Scheibe型, 4. Alexander 型)(表 2 ) が知られており, !最近では, Suehi-
3 乳頭径で卵円形の灰白色を呈する黄斑部欠損 (Macular Coloboma) を認め，脈絡膜血管が 透見された（図 5 ).

3 . 頸部所見 ; 頸椎 $X$ 線撮影にて頸椎癒合 $\left(\mathrm{C}_{2}\right.$ $-C_{3}$ ) を認めた（図 6).

4. その他の検查所見; 血液一般検査にて異常 を認めず，Wassermann 反応および Toxoplasma 反応は陰性で，染色体は $44+\mathrm{XX}$ で正常 女性型であった。

按

表 1. Ormerod による内耳奇形の分類

1. Michel type : complete lack of development of the internal ear.

2. Mondini-Alexander type

$$
\begin{aligned}
& \text { development only of a single curved } \\
& \text { tube representing the cochlea and } \\
& \text { similar immaturity of the vestibule } \\
& \text { and canals. }
\end{aligned}
$$

3. Bing-Siebenmann type

underdevelopment of the mebranous labyrinth, particularly of the sense organ, with a well-formed labyrinth .

4. Scheibe type : malformation restricted to membranous cochlea and saccule.

表 2. Schuknechtによる内耳奇形の分類

1. Michel type : complete failure of development of the inner ear.

2. Mondini type : imcomplete development of the bony and mebranous labyrinth.

3. Scheibe type : cochleosaccular aplasia

4. Alexander type : membrano:s cochlear aplasia

$\mathrm{ro}^{8)}$ らが，新しい分類法を提唱している。乙れ らはいずれも病理組織学的分類であるため, 臨 床的に骨迷路の異常を有する Michel 型やMondini (Mondini-Alexander) 型をX線を用い 
て診断することは可能であるが，他の型は膜迷 路の異常のために, 生前に診断することは不可 能である。

Valvassori i $^{9}$ が内耳奇形の診断に多軌道断層 撮影の応用を報告して以来, $\mathrm{X}$ 線学的に内耳奇 形の分類が試みられており10)，また，最近では 側頭骨 CT を用いて従来のX線学的観察より 詳細に内耳奇形を観察している報告3) ある。 すなわち, Everberg(1)によれば，片側血122名 中22名に前庭機能の久如抢よびX線的に異常を 認め, このうち20名に側頭骨 polytomography を行い, 2 名 (1.6\%) に内耳の空洞奇形（solitary sac-like deformity)を認めている。本邦

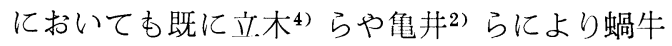
が欠如し前庭, 半規管に相当する部位が囊胞状 を示す内耳奇形の症例が報告されており，立木 ら ${ }^{12)}$ は，X線学的に診断可能な骨迷路奇形を古 典的な Michel 型, Mondini 型に加え, 蝸牛 が欠如し前庭。半規管が一部チステ様になった 型と, 蝸牛は正常で前底半規管に種々の程度の 形態異常のある型を追加すべきであるとして， 螖牛が火如儿前庭・半規管が囊胞状を呈する内 耳奇形を内耳空洞奇形と呼んでいる。最近, 村 田ら ${ }^{3)}$ は, 前庭に相当する部位に空洞様奇形を 認めた内耳を側頭骨 CT にて精査し, 蝸牛の分 化が初期に停止したと思われる所見を認め,

Mondini-Alexander 型の範疇に入れ, 側頭骨 CTにより内耳奇形の形態学的特徴を, 儖床の 段階で詳細に観察できることを強調している。

黄斑部欠損症は, 黄斑部中心窩を含む円形な いし楕円形の非定的型的脈欠損で，その成因に は諸説があるが, 吉阙ら ${ }^{14)}$ は, 組織学的所見か ら神経外肧葉外層の分化の異常之内層の増殖が 重要な役割を果たすと述べている。本邦の報告 例中, 両親の血族結婚が44\%に認められるが, 家族内発生はみられていない。諸外国の報告で autosomal recessive, autosomal dominant など一定の遗伀形式を有する報告もみられ，一 般に前者の可能性が高いと言われている。本報 告例の場合, 両親の血族結婚はなく, 家系内に
同様症状を有する者むいなかった。

黄斑部火摃症と他の奇形が合併することは槛 めて稀であり，黄斑部火損に手足などの骨格の 奇形が合併した埸合. Sorsby 症候群と呼ばれ

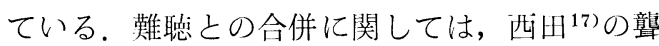

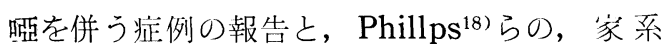
内に難聴者を認めたとの報告などがあり，稀で ある。耳奇形に眼奇形や頭頸部，四肢の形成異 常を伴う疾患には, Goldenhar 症候群, Treacher-Collins 症候群や Wildervanck 症候群 などが知られている。乙れらの疾患は，外耳， 中耳, 内耳奇形に頭部, 顔面, 几腔, 頸部の形 成異常や上下眼臉火裂, 眼臉火損, 結膜デルモ イド。動眼神経麻猈などの眼異常を有している が, 本報告例は, 内耳奇形, 頸椎瘉合に黄斑部 欠損を伴っており，てれまでの既知の症候群に あてはまらなかった。

内耳奇形々黄斑部火損求よび頸椎瘉合との関 連性を考えてみると，内耳奇形は，膜迷路の原 基である耳胞が，球形囊，螖牛管，卵形囊そし て三半規管へ分化する胎生第 4 週から 8 週まで の間に，何らかの原因でその分化が停止し生じ たものと考えられるが，本報告例の如き内耳空 润奇形 (solitary sac-like deformity) は, 耳 胞の形成される 4 から 6 週頃に発育が障害され たものと推定される。乙れに対して, 黄斑部の 発育過程の特徵は, 佐伯 ${ }^{19}$ によれば, 胎生 4 ケ 月初めに認識ができ, 中心召発生の特徵は 7 ケ 月に認められるとしている。黄斑部火損は, 神 経外胚葉の発生異常との説 ${ }^{14)}$ が有力であるが, 胎生期のどの時期での発生異常であるかは明ら かでない，内耳も神経外肧葉由来であり，発生 学的に同一機転により生じたものとも推察でき る。頸椎癒合は，胎生 3 週加 7 週の間におい て, 中肧葉硬結の正常の分節化の火宿による.川 胚葉性の異常であり，内耳奇形之同一時期の発 生異常と考えられる。したがって, 本症例は, 胎生の 4 週頃に神経外胚葉に由来する耳胞およ び眼胞や中胚葉性硬結に何らかの原因が働き, 内耳空洞奇形, 黄斑部久損, 頸椎癒合を生じた 
あのと考えられる。

結語

22歳の女性で, 内耳空洞奇形に両眼性黄斑部火損および頸椎癒合を伴った 1 症例を報告し，発生: 学的に文献的考察を加えた。

尚．本論文の要旨は，第10回日本臨休耳科学会において報告した。

\section{文献}

1）立术 孝，他：内耳空洞様奇形による一側高度難 聴の 1 例。日耳鼻 $74: 1353 \sim 1357,1971$.

2) 亀井民雄, 他：1側内耳単独奇形（X線的）の 2 症例。耳喉 $53: 7 \sim 13,1981$.

3）村田清高, 他：内耳奇形の 1 例一側頭骨 CT に上 る診断。耳鼻臨床 $75: 1047 \sim 1054,1982$.

4) Ormerod FC: The pathology of congenital deafness. J Laryngol Otol $74:$ 919 950, 1960.

5) Langman J : Medical Embryology 3rd Ed 108 〜34, Igaku Shoin Ltd, 1975.

6）秋吉正豊, 他：聴覚障害一基礎之臨林一, 朝倉書 店 1978 .

7) Schuknecht HF : Mondini dysplasia. Ann Otol Rhinol Laryngol 89: Suppl 65, 1980.

8) Suehiro $S$ and Sando I : Congenital a anomalies of the inner ear. Introducting a new classification of labrinthine anomalies. Ann Otol Rhinol Laryngol 88 : Suppl 59, 1979.

9) Valvassori GE, et al: Inner ear anomalies : Clinical and histpathological considerations. Ann Otol Rhinol Laryngol $78: 929 \sim 938$, 1969.

10) Phelps PD : Congenital lesions of the inner ear, Demonstrated by tomography. Arch Otolaryngol 100:11 18, 1974.

11) Everberg G : Investigations into unilateral total deafness and absence of vestibular function with a particular view to the X-ray appearance in the inner ear. Acta Otolaryngol $59: 47 \sim 62,1960$.

12）立木 孝, 他：内耳奇形の臨床的研究，特にその 分類法について。臨床耳科 $3: 138 \sim 139,1976$.

13）岩村節子, 他：レントゲン所見で発見された一側 性内耳奇形。臨床耳科 $8: 88 \sim 89,1981$.

14）吉岡久春, 他: 先天性黄斑部欠損症の病理組織所 見と其の成因. 眼臨 $58: 1016 \sim 1020 ， 1964$.

15) Phillips $\mathrm{CI}$, et al : Macular coloboma and skeletal abnormality. Brit J Ophthalmol $53: 346$ $\sim 349,1969$.

16) Sorsby A : Congenital coloboma of the macula : together with an account of the familial occurrence of bilateral macular coloboma in association with apical dystrophy of hands and feet. Brit J Ophthalmol $19: 65 \sim 90$, 1935.

17）西田時子：先天性束状剝䙰様の乳頭部变状を呈し た両眼性黄琉欠損の一例。眼臨 $60: 385,1966$.

18) Phillips $\mathrm{Cl}$, et al : Congenital maculart " $\mathrm{COL}$ OBOMA" and retinal aplasia, Acta Ophhalmol $59: 894 \sim 1981$.

19）佐伯 譲：本邦人胎児黄斑部の発青過程について (II). 眼臨 $13: 841 \sim 844 ， 1959$.

$$
\left(\begin{array}{l}
\text { 別刷請求先: 安斎友博 } \\
\mathbf{T} 960 \text { 福島市杉妻町 } 4-45 \\
\text { 福島県立医科大学耳鼻咽喉科学:教室 }
\end{array}\right)
$$

